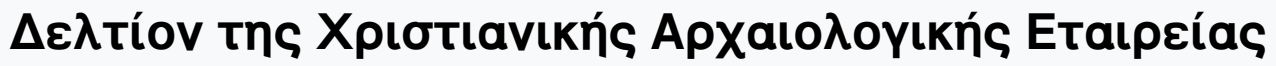

Tó 37 (2016)

$\Delta \varepsilon \lambda$ tíov XAE 37 (2016), Пврíoঠos $\Delta^{\prime}$

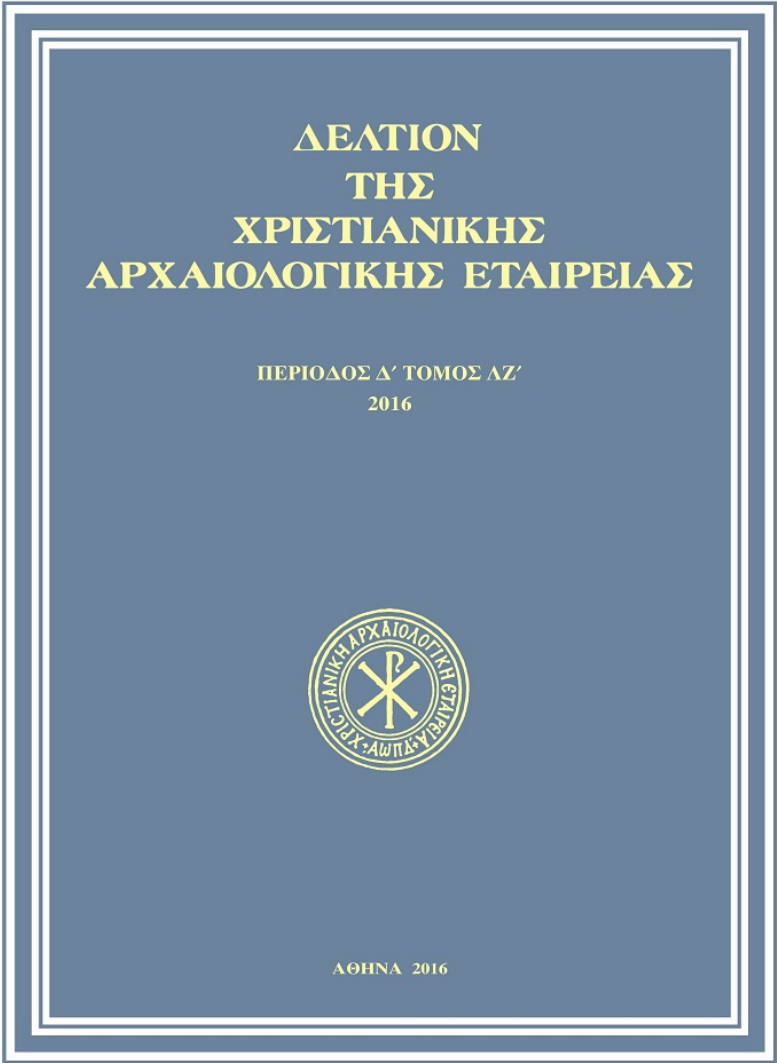

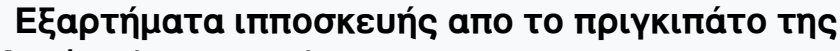
Axaïas (1205-1428)

Eleni BARMPARITSA

doi: $10.12681 /$ dchae.10701

Copyright @ 2016, Eleni BARMPARITSA

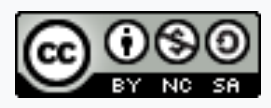

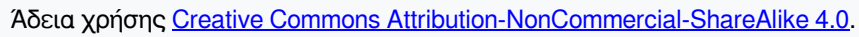

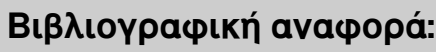

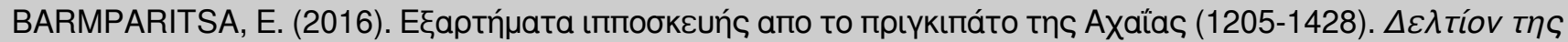

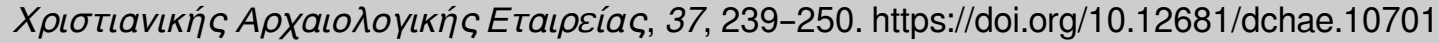




\section{Eleni Barmparitsa}

\section{RIDING EQUIPMENT \\ FROM THE PRINCIPALITY OF ACHAEA (1205-1428)}

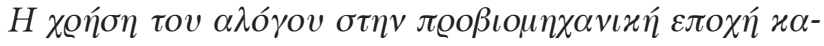

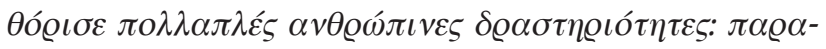

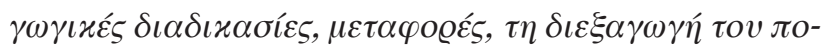

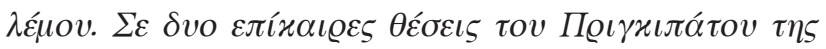

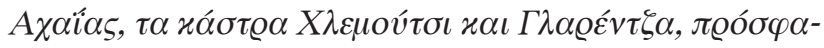

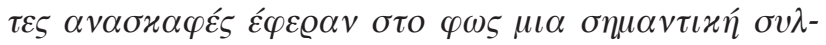

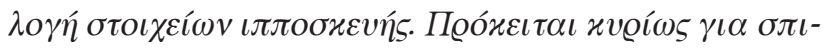

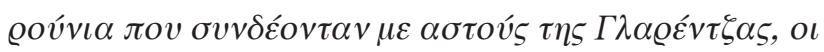

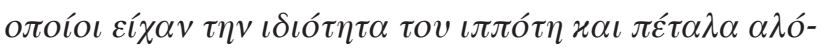

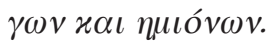

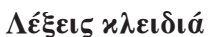

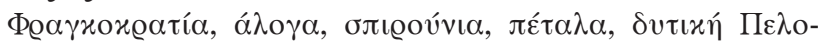

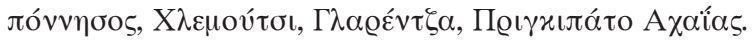

$\mathrm{T}_{\mathrm{t}}$ he Principality of Achaea was the largest of a series of states formed in Greece after the Fourth Crusade in 1204, which resulted to the sack of Constantinople by the knights of Western Europe ${ }^{1}$. The castles of Chle-

\footnotetext{
*Dr. Archaeologist, lenabarmparitsa@gmail.com

** I express my gratitude to Mr. Chris J. Milnes for the editing of my text.

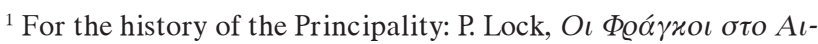
roío, 1204-1500, Athens 1998. A. Lambropoulou - A. Panopou-

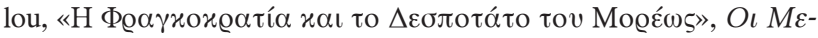

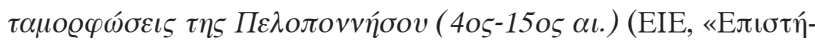

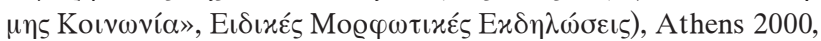

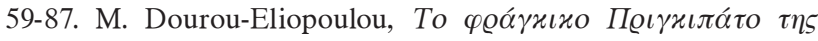

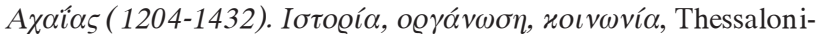
ki 2005, with previous bibliography. D. Jacoby, «After the Fourth Crusade: The Latin Empire of Constantinople and the Frankish States», The Cambridge History of the Byzantine Empire, $c$. 500-1492, ed. J. Shepard, Cambridge 2008, 759-778. F. Sampsonis, «L'administration de la Morée par Charles Ier d'Anjou (1267-1285). L'apport majeur d'une source délicate: les registres angevins», Mélanges de l'École française de Rome, Moyen Âge
}

The use of the horse in pre-industrial societies improved a series of human activities, including production processes,transportation, and military activities. Recent excavations at two important sites in the Principality of Achaea (1205-1428), the castles of Chlemoutsi and Glarentza in Western Peloponnese, revealed a significant collection of riding equipment. The collection consists mainly of spurs for the citizens of Glarentza who held the status of knight, as well as horseshoes for war horses and pack animals.

\section{Keywords}

Frankish period, horses, spurs, horseshoes, Western Peloponnese, Chlemoutsi, Glarentza, Principality of Achaea.

moutsi and Glarentza, which were constructed in the 13th century at the westernmost tip of the Peloponnese, were the Principality's administrative and economic centres $^{2}$ (Figs 1, 2).

120/1 (2008), 139-157. Ead., «La place de la Morée franque dans la politique de Charles Ier d'Anjou (1267-1285)», REB 69 (2011), 81-109.

${ }^{2}$ A. Bon, La Morée franque. Recherches historiques, topographiques et archéologiques sur la principauté d'Achaïe (1205-1430) (Bibliothèque des Écoles françaises d'Athènes et de Rome 213), Paris 1969, 320-328, 602-629. K. Andrews, Castles of the Morea, rev. ed. G. R. Bugh, Princeton 2006², 146-158. E. Sarandi-Mendelo-

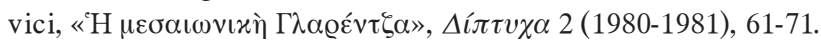
O. Schmitt, «Zur Geschichte der Stadt Glarentza im 15. Jahrhundert», Byz 65 (1995), 98-135. D. Athanasoulis - A. Rally (eds), $\Gamma \lambda \alpha \varrho \varepsilon ́ v \tau \xi \alpha-$ Clarence, Athens 2005. A. Tzavara, Clarentza, une ville de la Morée latine, XIIIe-XVe siècle (Institut Hellénique d'Études Byzantines et Post-byzantines de Venise, Tommaso Flanghini 3), Venice 2008. D. Athanasoulis, «The Triangle of Power: Building Projects in the Metropolitan Area of the Crusader Principality of the Morea», Viewing the Morea. Land and People in the Late Medieval Peloponnese, ed. S. E. J. Gerstel, (Dumbarton 


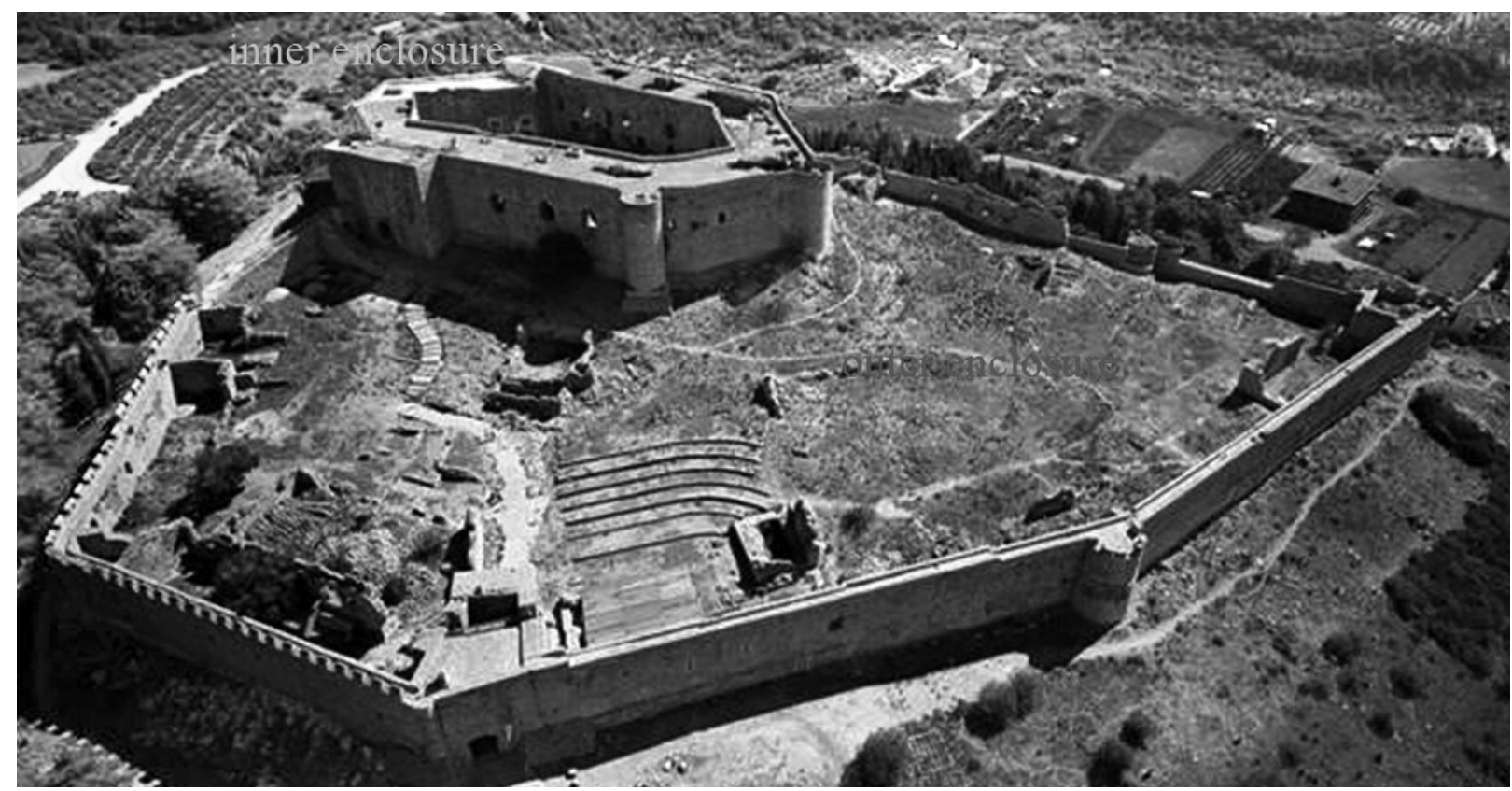

Fig. 1. The castle of Chlemoutsi, aerial photograph.

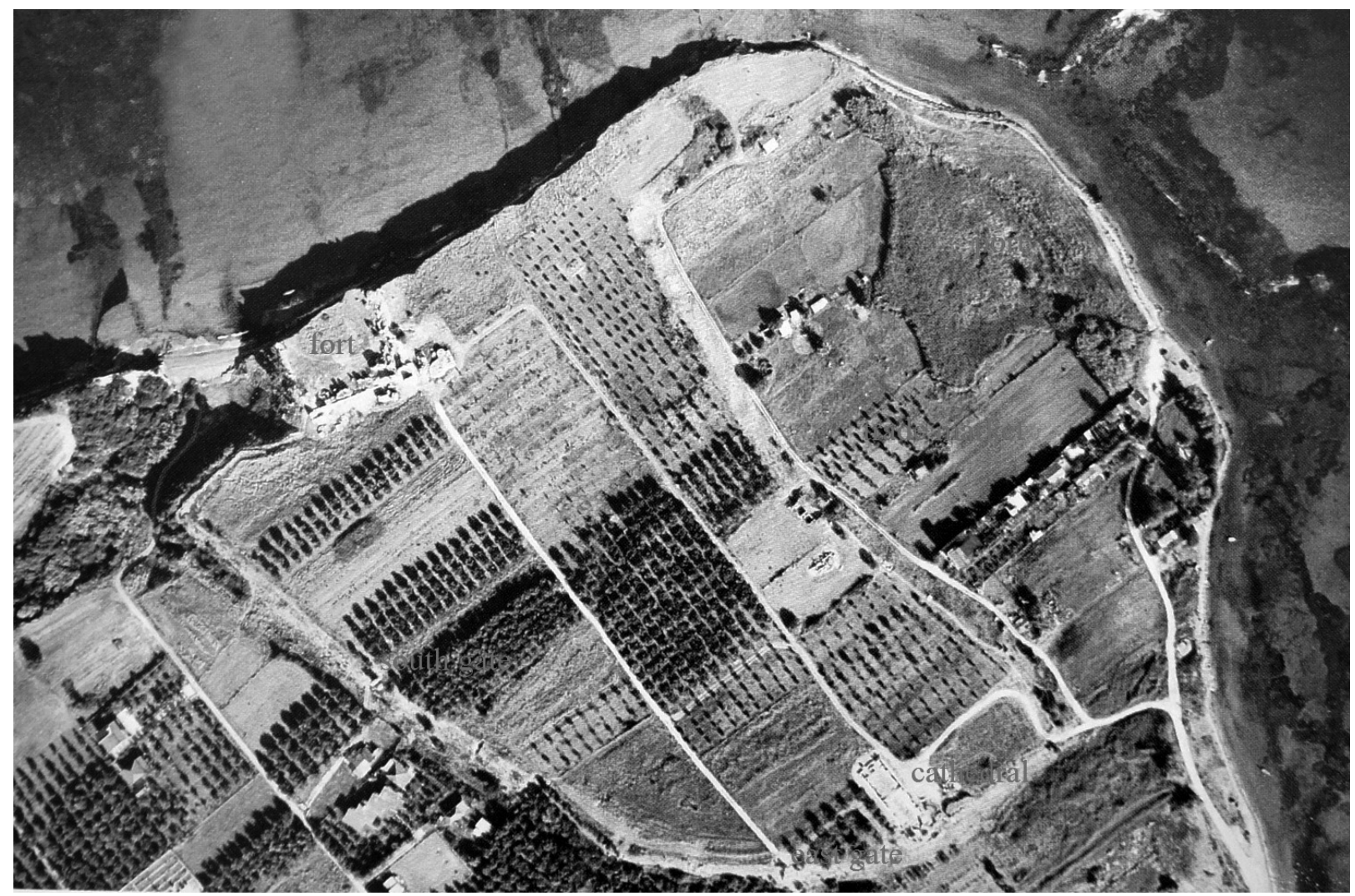

Fig. 2. The castle of Glarentza, aerial photograph. 
In the 13th century, when the Principality was run by the Villehardouin family from Champagne, the court of Achaea, described as «nova francia», was thought by the contemporary Westerners to capture the chivalric ideals ${ }^{3}$ that are reflected in the main written source of that period, the Chronicle of Morea, a verse narrative about the conquest of the Byzantine Peloponnese by the Franks, which survives in four language versions ${ }^{4}$. According to the information drawn mainly from the Chronicle, the cavalry was a key part of the Principality's Frankish army 5 . Additional data derived from sigillography indicate that horses symbolised the strength and dominance of its ruling class ${ }^{6}$ (Fig. 3).

Horse equipment during the Late Middle Ages included direction and control gear (mouthpiece, bridles, spurs), gear used by the rider (saddle, stirrups), protective gear for the animal (armour) as well as various decorative elements (fittings, bells). The horse's gear entailed a great $\operatorname{cost}^{7}$. Leather and iron were the most preferred materials and were used in different variations depending on the economic strength of the horse's owner. Precious metals, which may be suggested by the

Oaks Symposia and Colloquia), Washington, D.C. 2013, 111-151, with extended bibliography. Id., «Clermont-Chloumoutzi. Le château-palais francs d'Achaïe», Un palais dans la ville. Le Palais des rois de Majorque à Perpignan, eds P. Passarius - A. Catafau, 1, Perpignan 2014, 337-357.

${ }^{3}$ Regesta Honorii Papae III, ed. P. Pressutti, 2, Rome 1895, item 5006. D. Jacoby, «Knightly Values and Class Consciousness in the Crusader States of the Eastern Mediterranean», Mediterranean Historical Review 1 (1986), 158-186 (= D. Jacoby, Studies on the Crusader States and on Venetian Expansion, Aldershot 1989, no. I). T. Shawcross, The Chronicle of Morea: Historiography in Crusader Greece, Oxford - New York 2009, 6, 21-22 and passim.

${ }^{4}$ The Chronicle of Morea. A History in Political Verse Relating the Establishment of Feudalism in Greece by the Franks in the Thirteenth Century, ed. J. J. Schmitt, London 1904. Especially for the Chronicle of Morea as an historical source, G. Page, Being Byzantine. Greek Identity Before the Ottomans, Cambridge University Press 2008, 177-242. Shawcross, The Chronicle of Morea, op.cit. (n. 3). M.-H. Blanchet - G. Saint-Guillain, «A propos d'un ouvrage récent sur la Chronique de Morée: Contribution au débat», Byz 83 (2013), 13-35.

${ }^{5}$ Chronicle of Morea, op.cit. (n. 4), ver. 858, 1069, 1145.

${ }^{6}$ G. Schlumberger - F. Chalandon - A. Blanchet, Sigillographie de l'orient latin, Paris 1943, 185-186, pls IX.2, XXI.2.

${ }^{7}$ N. Oikonomides, «The Contents of the Byzantine House from the Eleventh to the Fifteenth Centuries», DOP 44 (1990), $211 \mathrm{n}$.

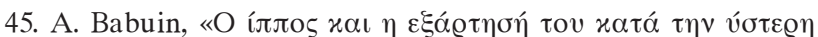

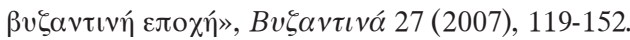

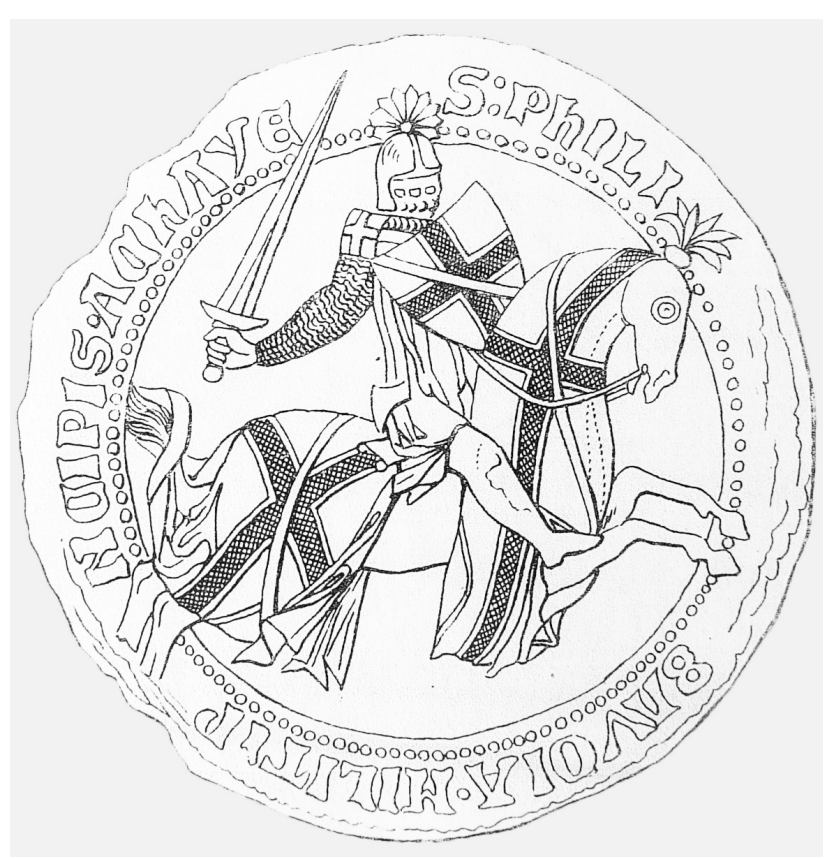

Fig. 3. Seal imprint of prince Philip of Savoy (1301-1305).

iconography or referred to in sources, were not found in the excavations, meaning that they were most probably recycled ${ }^{8}$. The use of various metal objects (buckles, fittings, bells, rings, decorative mounts) which may be connected to the horse's equipment as well as to the rider's attire, is also difficult to determine ${ }^{9}$.

The excavations that took place between 2000 and 2005 in the castles Glarentza and Chlemoutsi by the Archaeological Service of the Greek Ministry of Culture, under the supervision of the archaeologist Dr. Demetrios Athanasoulis revealed, amongst other things, a set of objects associated with the gear and control of the horses, hence confirming the close relationship that medieval knights had with them, also established from the chivalric romances of the time.

The finds included sets of spurs, spur buckles and fittings excavated from the funerary ensembles of the

\footnotetext{
${ }^{8}$ J.-J. Schwien - Y. Jeannin, «Loger, nourrir, équiper le cheval: un essai de synthèse pour la seconde partie du Moyen Âge dans l'Est de la France et ailleurs», Le cheval dans les sociétés antiques et médiévales, ed. S. Lazaris (Bibliothèque de l'Antiquité tardive 22), Paris 2012, 115, 117.

${ }^{9} \mathrm{C}$. Enlart, Manuel d'archéologie française depuis les temps mérovingiens jusqu'à la Renaissance, III, Le costume, Paris 1916, 250.
} 
Glarentza cathedral, from a pottery depository found at the eastern gate of the city as well as from the site of its fort (Fig. 2). Spurs and additional fittings are dating from the late 13 th to the early 15 th century, as established by the excavation context and the subsidiary finds mainly coins and pottery shards ${ }^{10}$. Most horseshoes were excavated from the inner enclosure of the Chlemoutsi castle (Fig. 1). However, no information could be drawn regarding the horses' armour, probably because of the main use of organic materials which were more suitable in hot climates ${ }^{11}$.

The use of spurs while riding was ancillary and is linked to the growing use of horses and the finalisation of saddlery equipment by the 9th century. During the Late Middle Ages, in addition to serving the practical needs of the rider, spurs indicated social status and, if clad with gold, were also seen as chivalric symbols ${ }^{12}$. Ma-

\footnotetext{
${ }^{10}$ For the finds of the recent excavations at Glarentza, D. Athanasoulis - J. Baker, «Medieval Clarentza, The coins 1999-2004, with additional medieval coin finds from the nomos of Elis», The Numismatic Chronicle 168 (2008), 241-301. Athanasoulis - Rally, $\Gamma \lambda \alpha \varrho \varepsilon \varepsilon v \tau \xi \alpha$, op.cit (n. 2), 44-49 (A. Konstantinidou - A. Rally).

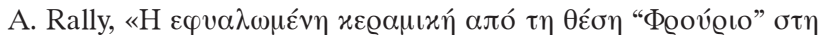

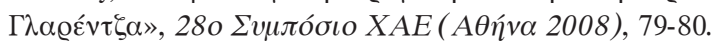

${ }^{11}$ During the Middle Byzantine period the horses were protected in the vital parts of their bodies with pieces of felt, iron, leather or horn, J. F. Haldon, «Some Aspects of Byzantine Military Technology from the Sixth to the Tenth Centuries», Byzantine and Modern Greek Studies 1 (1975), 20, 22, 38. T. G. Kolias, Byzantinische Waffen. Ein Beitrag zur byzantinischen Waffenkunde von den Anfängen bis zur lateinischen Eroberung (Byzantina Vindobonensia 17), Vienna 1988, 51-55. Id., «The Horse in the Byzantine World», Le cheval dans les sociétés antiques et médiévales, ed. S. Lazaris, (Bibliothèque de l'Antiquité tardive 22), Paris 2012, 92.

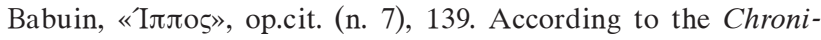
cle of Morea the rival troops were striking with arrows the horses of the Frankish army, thus disorganising the cavalry, which was the main unit of the army, Chronicle of Morea, op.cit. (n. 4), ver. 1069, 1144-1145. By 1272, the cavalry of the Principality of Achaea was mainly using uncovered or partly armoured war horses, J. Wilskman, «The Conflict between the Angevins and the Byzantines in Morea in 1267-1289: A Late Byzantine Endemic

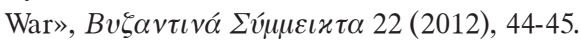

${ }^{12}$ E. M. Jope, «The Tinning of Iron Spurs: A Continuous Practice from the Tenth to the Seventeenth Century», Oxoniensia 21 (1956), 35-42. J. Gies - F. Gies, Life in a Medieval Castle, New York 1974, 166-169. L. White Jr., Medieval Technology and Social Change, Oxford 1962, 150. Since early 12th century only the anointed knights earned the right to wear golden spurs and the Crusaders are thought to mainta in the rituals of their places of origin, T. Jones, Chaucer's Knight: The Portrait of a Medieval Mer-
}

rino Sanudo Torsello reveals that prince Geoffrey II of Villehardouin (1228-1246) maintained in his court, on a permanent basis and at his own expense, eighty knights with golden spurs ${ }^{13}$.

A set of twelve spurs, recovered primarily from burial layers in the graves of Glarentza, are important examples of riders' gear and demonstrate that the graves of the cathedral were intended for the members of the Principality's upper classes who had attained the status of knighthood. These spurs were mostly made of gilded iron (Figs 4, 5). Two intact copper alloy samples were also found (Figs 6, 7).

All the excavated spurs are variants of the same type, with a revolving six-point or eight-point rowel, a type which according to the information gathered so far, was found in Greece by the end of the 13th century onwards ${ }^{14}$. The iron spurs are a little smaller compared to the copper ones, with a length ranging from $11.3 \mathrm{~cm}$ to $12.65 \mathrm{~cm}$ and a plate thickness of 1.2 to $1.8 \mathrm{~cm}$. The respective bronze ones have an average length of 14.2 $\mathrm{cm}$ and are thinner, with an average plate thickness of $0.7 \mathrm{~cm}^{15}$. Almost all of them have copper fittings (hooks)

cenary, London 1980, 18-19. Babuin, «Iллo5», op.cit. (n. 7), 136.

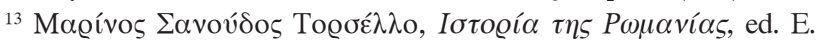

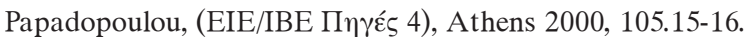

${ }^{14}$ Iron spur, today in the Byzantine Museum of Athens, was excavated from the medieval site of Akraifnion in Boeotia, Greece, and is dated to the end of the 13th century, Ch. Koilakou,

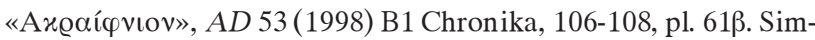
ilar unpublished spur was excavated at the site of Aghia Triada, Thebes (Ephorate of Antiquities of Boeotia / Medieval Collection, cat. number: 5130). For the information I express my gratitude to the archaeologist Giann is Vaxevanis. Similar spurs have been revealed in the grave of a knight at the church of Episcopi at

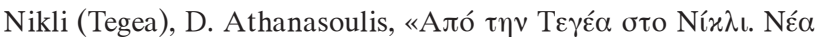

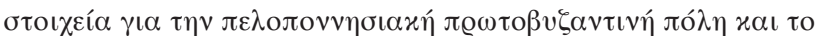

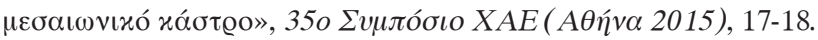
${ }^{15}$ Rowel spurs in early depictions originating from several sites of Western Europe appear of modest dimensions, rather thin, with deeply curved sides and small rowels, see G. Masson, «Horse Management in Medieval Renaissance Italy», Country Life Annual 1952, 188. B. M. A. Ellis, «Spurs and spur fittings», The Medieval Horse and its Equipment c. 1150-1450, ed. J. Clark, (Medieval Finds from Excavations in London 5), London 1995 (repr. Woodbridge 2004), 128. N. Morgan, Early Gothic Manuscripts (I) 1190-1250. A Survey of Manuscripts Illuminated in the British Isles, London 1982, 130-133 no. 85, fig. 282. The same type of early rowel spurs was depicted in illuminated manuscripts created in Acre and Lombardy and dating to the last quarter of the 13th century, J. Folda, Crusader Manuscript Illumination at Saint-Jean 

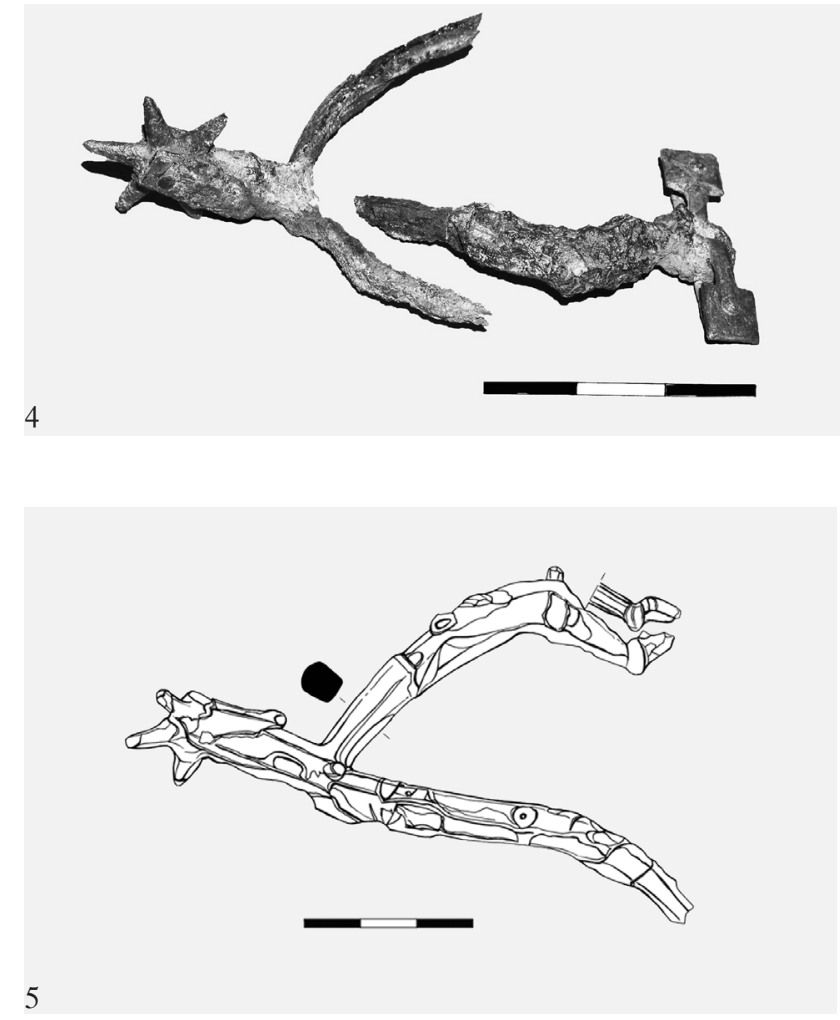

Fig. 4. Glarentza, from the graves of the cathedral. Rowel spur, gilded iron, end of 13th - middle 14th century (Inv. Number: HM485).

Fig. 5. Glarentza, from the graves of the cathedral. Rowel spur, gilded iron, end of 13th - middle 14th century, drawing (Inv. Number: HM487).

Fig. 6. Glarentza, from the graves of the cathedral. Rowel spur, copper, middle 14th - early 15th century, drawing (Inv. Number: HM776).

Fig. 7. Glarentza, from the graves of the cathedral. Rowel spur, copper, middle 14th - early 15th century, drawing (Inv. Number: HM777).

and small buckles that attach them to the rider's shoes (Figs 4, 6-13).

Regarding the spurs found in Glarentza, it can be traced a typological development in the way the strap was attached, which also constitutes a chronological

d'Acre, 1275-1291, Princeton 1976, 188-192 no. 10, 199-200 no. 19 , figs 71,188 .
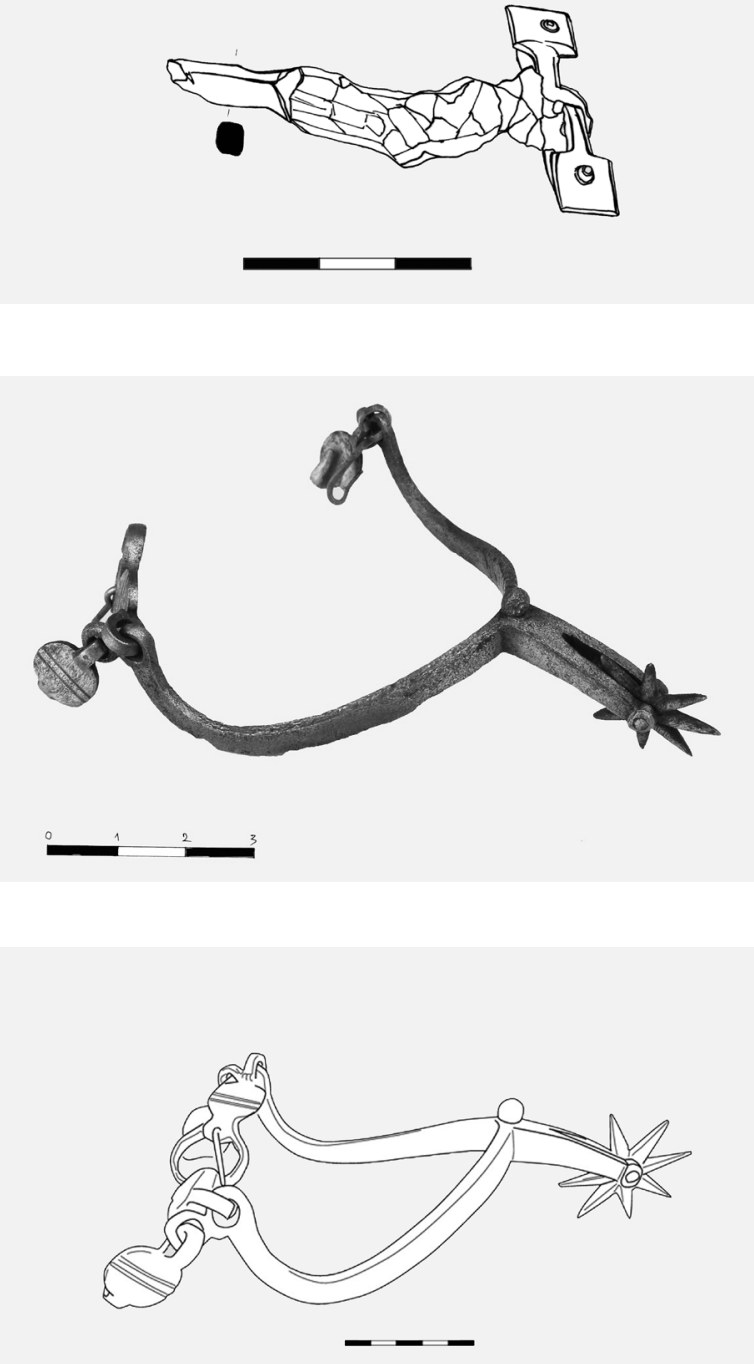

evolution. More precisely, from the end of the 13th to the mid 14th century, the spur shanks ended in a circular and a rectangular hole respectively (Figs 4, 5). Two small rivet attachments joined to the circular hole (Figs $4,12)$. The attachment located on the exterior side of the foot, retained the leather strap. The strap went around the rider's footwear, passed through the rectangular hole of the other shank and fastened with a buckle. The buck- 
le was suspended from the second rivet attachment of the circular hole ${ }^{16}$. The majority of the iron spurs from Glarentza was of that particular kind, and could hence be dated from the late 13th century (Figs 4, 5).

However, from the mid 14th century onwards, most spurs had two leather straps, passing over and under the footwear of the rider and joined themselves to the shanks with separate rivet attachments. This marked a change in the edges of the shanks, each of which now included two small holes alongside one another (Figs 6, 7). The one hole restrained the small buckle ${ }^{17}$. Intact bronze spurs of Glarentza fall in this category, hence indicating that they date from the mid 14th century.

Predominantly iron rowel spurs are often found in excavations in the Eastern Mediterranean dating from the late 13 th century onwards ${ }^{18}$. Gold-plated and decorated spurs were an indispensable complement to the upper class male attire during the Late Middle Ages and are depicted in various forms of $\operatorname{art}^{19}$.

${ }^{16}$ Ellis, «Spurs», op.cit. (n. 15), 127-130, fig. $95,133-134$ no. 323 , fig. 91 .

${ }^{17}$ Ibid., 127-128, 139 no. 333, 335, 141-142 no. 341. M.-L. Laharie - J.-C. Tréglia - M. Brion, «Le castrum de Montpaon (Fontvieille, Bouches-du-Rhône). Observations préliminaries», Archéologies de Provence et d'ailleurs. Mélanges offerts à Gaëtan Congès et Gérard Sauzade, BAP Supplément 5 (2008), 757-758, fig. 7.7-8.

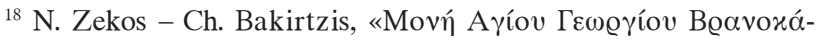

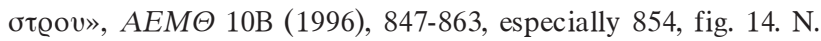

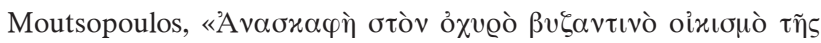

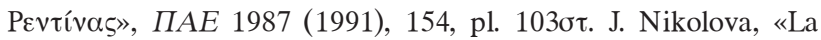
vie domestique et l'armement dans le Palais de Carevec d'après le matériel archéologique», Le Palais des rois bulgares pendant le deuxième royaume bulgare (XIIe-XIVe siècle), II: Céramique, objets domestiques et armement, parures et tissus, ed. C. Târnov, Sofia 1974, 309-310, fig. 120. P. Diaconu - S. Baraschi, Păcuiul lui Soare. 2. Aşezarea medievală (secolele XIII-XV), II, Bucharest 1977, 215 pl. XXII4-6. F. Caillaud, «Scribla: le matériel métallique d'un site calabra is fortifié (Xe-XVe siècles)», Artistes, artisans et production artistique au Moyen Âge, Colloque international, Centre National de la Recherche Scientifique, Université de Rennes II - Haute-Bretagne, 2-6 mai 1983, ed. X. Barral I Altet, II, Paris

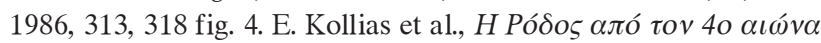

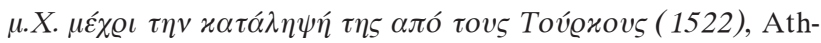
ens 2004, 64, fig. 74 no. 44. J. Charles-Gaffiot (ed.), La France aux Portes de l'Orient: Chypre XIIème-XVème siècle, Paris 1991, 50. Ellis, «Spurs», op.cit. (n. 15), 133-150.

${ }^{19}$ The rowel spur can be traced in the art of the Angevin kingdom of Naples as well as the regions of the Greek peninsula under Latin occupation, by the first third of the 14th century, S. Bridges - J. Ward Perkins, «Some Fourteenth Century Neapolitan Military Effigies», Papers of the British School at Rome 24 (1956), 172, pl.

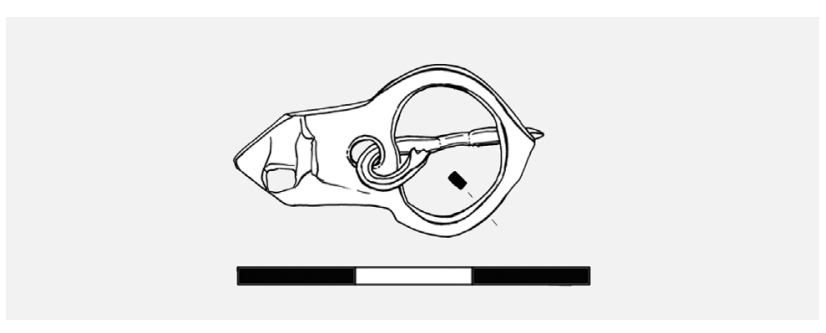

Fig. 8. Glarentza, from the graves of the cathedral. Spur buckle, copper, late 13th - early 15th century, drawing (Inv. Number: HM484).

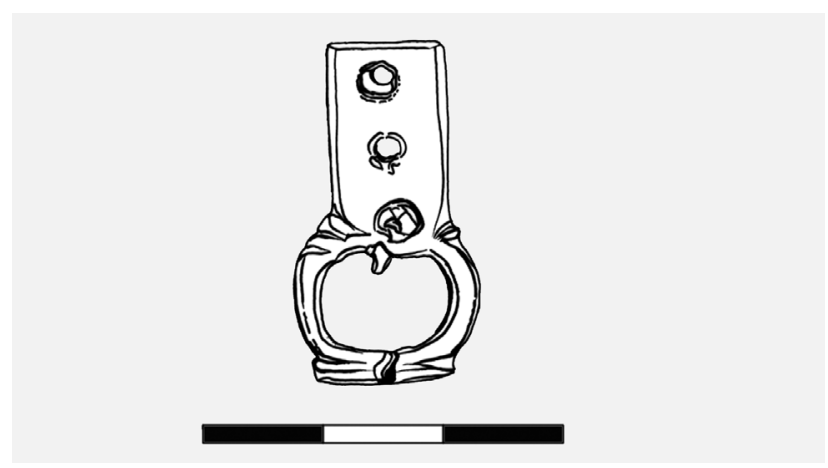

Fig. 9. St. Nicholas at Trianta, from the graves of the nave. Spur buckle, copper, late 13th - early 15th century, drawing (Inv. Number: HM489.ß).

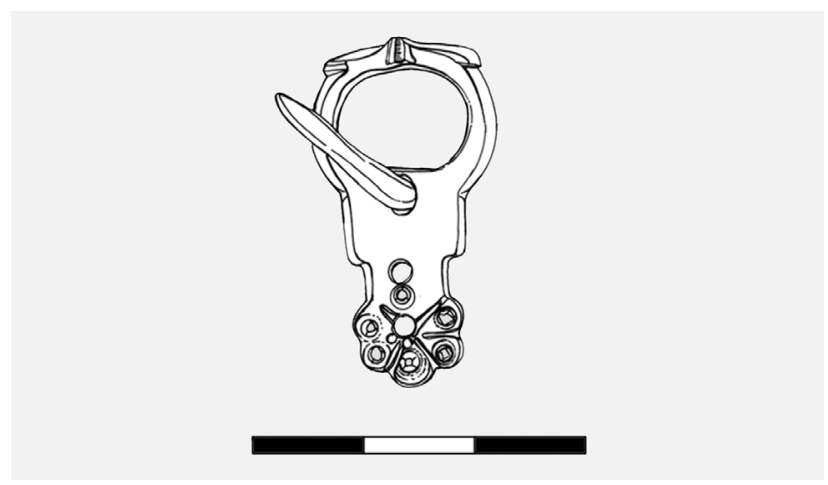

Fig. 10. Glarentza, from the graves of the cathedral. Spur buckle, copper, late 13th - early 15th century, drawing (Inv. Number: HM901.及)

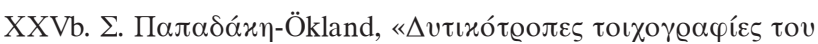

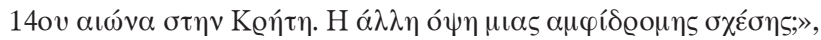

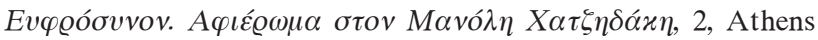
1992, 504-505, pl. 31, fig. 264a. I. Spatharakis - T. Van Essenberg, Byzantine Wall Paintings of Crete, III: Amari Province, Leiden 2012, fig. 70. A. Lymberopoulou, The Church of the Archangel 


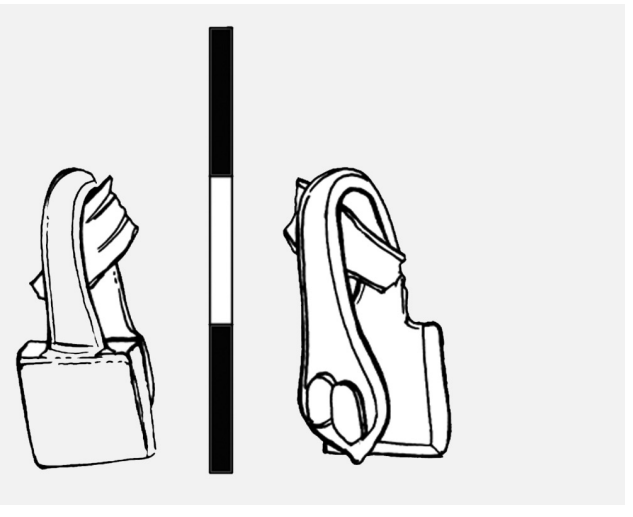

Fig. 11. Glarentza, from the graves of the cathedral. Spur fitting, copper, late 13th - early 15th century, drawing (Inv. Number: HM821)

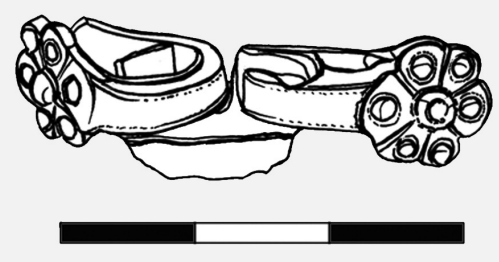

Fig. 12. Glarentza, from the graves of the cathedral. Spur fitting, copper and iron joint, late 13th - early 15th century, drawing (Inv. Number: HM903.及).

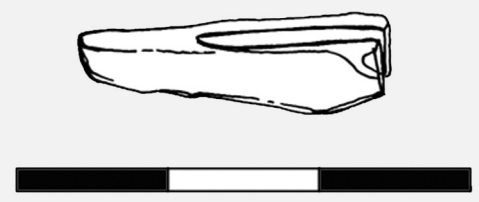

Fig. 13. Glarentza, from the graves of the cathedral. Spur fitting, copper, late 13th - early 15th century, drawing (Inv. Number: HM805).

Michael at Kavalariana. Art and Society on Fourteenth century Venetian-dominated Crete, London 2006, 107-108, 367 fig. 33.

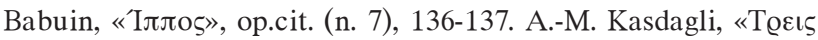

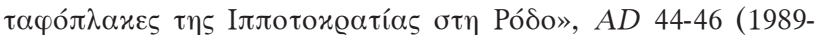
1991), Meletes, 191-193, pl. 77. In the Peloponnese region, a rowel spur is depicted in a miracle of saint George on horseback, from
In most cases, individual small buckles and rivet attachments, which served to fasten the spur to the rider's footwear, were also found together with the spurs. The buckles excavated at the Glarentza cathedral are all made of copper and are a variation of a simple type with an elongated attachment shank and a circular or oval frame on which a thin pin is attached (Figs 7-10). The larger buckles usually have rectangular attachment shanks which are fastening to the leather straps through pins or hooks.

Spur equipment also includes the different strap attachments, which fall into two categories: those that join the spurs' metal shanks to the straps (Figs 4, 11, 12), and those that are placed at the end of the leather strap to protect it from getting worn out (Fig. 13).

The simple typology and the strong similarity observed between most of the copper spur attachments that were excavated at Glarentza, along with the need to immediately repair those objects that were of great practical utility, leads us to the assumption that the simplest among the rivet attachments could have been produced locally. Gilded iron spurs from the same funerary ensembles of the cathedral must have come from the same workshop, as well as the buckles and the attachments associated with them. The buckles and the fastening accessories with rosette decoration possibly belong to the same pair of spurs (Figs 10, 12).

By the first decade of the 15th century, the neck of the rowel spurs starts to become longer and thinner ${ }^{20}$.

the church of St. George in Longanikos, dated by 1374/5, O. Chassoura, Les peintures murales byzantines des églises de Longanikos -Laconie-, Athens 2002, 178-180, fig. 5. A rowel spur of significant diameter can be discerned in the depiction of a military saint on horseback from the church of Agioi Asomatatoi at Flomochori in Mani, N. Drandakis - E. Dori - S. Kalopissi - M. Panagiotidi,

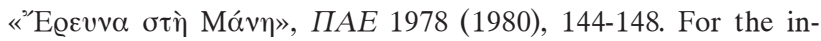
formation I express my gratitude to the archaeologist Michalis Kappas.

${ }^{20}$ The long neck of the rowel spurs was probably meant to help in the control of the armored horses, as it could slip under the joints of the armor, Dictionary of the Middle Ages, 3, «Cavalry, European» (C. M. Gillmor). R. Emmerson, «Design for mass production: monumental brasses made in London ca. 1420-1485", Artistes, artisans et production artistique au Moyen Âge, Colloque international, Centre National de la Recherche Scientifique, Université de Rennes II - Haute-Bretagne, 2-6 mai 1983, ed. X. Bar-

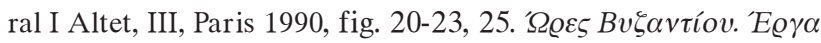

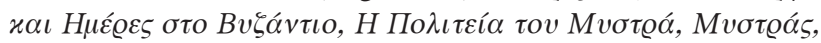


Although more practical spurs with short necks also existed during that period, the absence of spurs with long necks in the burial layers of Glarentza is an additional clue which establishes their upper date limit maximum circa 1400 , evidence which coincides with the historical inference regarding the town's decline during the first quarter of the 15 th century ${ }^{21}$.

Iron horseshoes adapted with nails to protect the horse's hoof, were an important innovation allowing for a safer tread on uneven ground and thus improving travelling conditions, allowing heavier cargo to be carried at a greater distance, increasing performance in agricultural activities and ensuring greater security when conducting military operations ${ }^{22}$. The first reference to the use of iron horseshoes is made in an anonymous military handbook of the 6th century Byzantine period, although their use became widespread during the 9th century ${ }^{23}$.

Twelve horseshoes that came mostly from excavation sections at the castles of Chlemoutsi and Glarentza are divided in two categories based on their typology. The first category includes compact «oriental-type» horseshoes, used until recently in Greece for the shoeing of mules (Fig. 14). Similar horseshoes, dating from the 9th century onwards, originated in Greece and the Balkans $^{24}$. Semicircular horseshoes, used on horses, were

Av́rovotos 2001 - Iavová@ıos 2002 (exhibition catalogue), eds P. Kalamara - A. Mexia, Athens 2001, 130 fig. 154.

${ }^{21}$ Schmitt, «Glarentza», op.cit. (n. 2), 134. Bon, Morée franque, op.cit. (n. 2), 324.

${ }^{22}$ S. Lazaris, «Rôle et place du cheval dans l'Antiquité tardive:

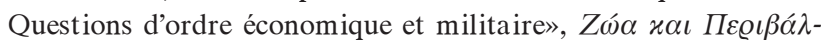

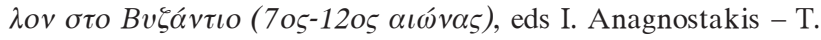
G. Kolias - E. Papadopoulou, (EIE/IBE, $\Delta\llcorner\varepsilon \theta v \eta ́ ~ \Sigma v v \varepsilon ́ \delta \varrho \iota \alpha ~ 21)$, Athens 2011, 252-253.

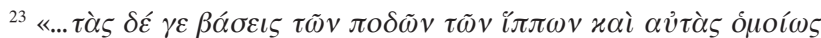

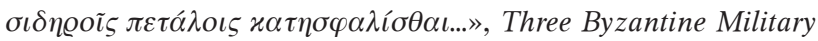
Treatises, ed. G. T. Denn is (CFHB 25), Washington, D.C. 1985, 56-

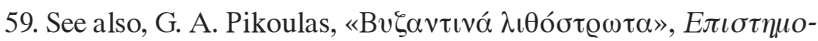

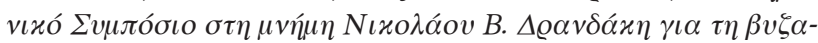

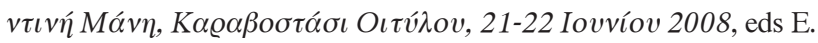
P. Eleftheriou - A. Mexia, Sparta 2008-2009, 82 and n. 4. S. Lazaris, «Considérations sur l'apparition du fer à clous: Contribution à l'histoire du cheval dans l'Ant iquité tardive», La veterinaria antica e medievale. Testi greci, latini, arabi e romanzi, Atti del II Convegno internazionale, Catania 3-5 ottobre 2007, eds V. Ortoleva M. R. Petringa, (Biblioteca di Sileno 2), Lugano 2009, 284-285. ${ }^{24}$ A compact horseshoe of the 9th-12th century is exhibited at the Byzantine Museum of Athens, Lazaris, op.cit. (n. 23),. fig. 6.

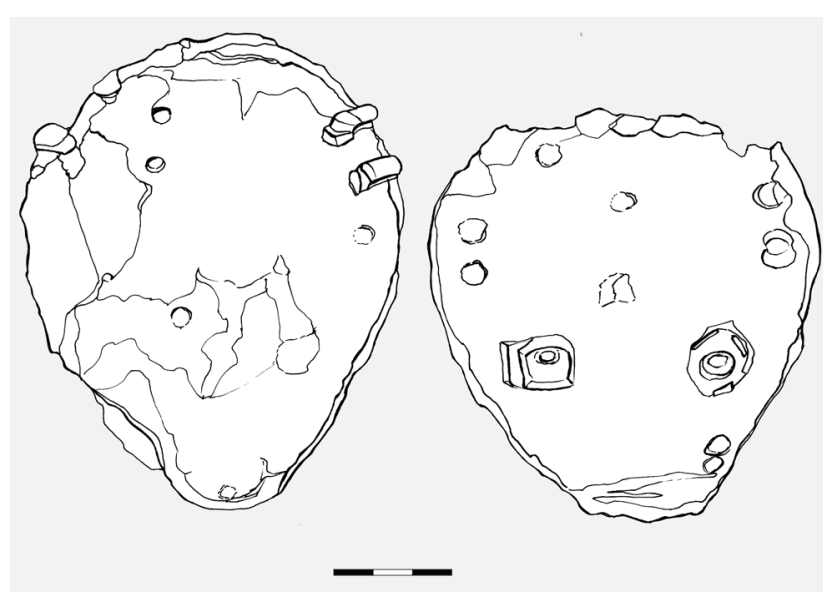

Fig. 14. Andravida, church of St. Sophia. Compact iron horseshoes for mules, late 13th - early 15th century, drawing (Inv. Number: HM472).

much more widespread (Figs 15-18). The subsidiary pottery finds allow us to date them from the late 13 th to the early 15 th century.

In the eastern Mediterranean, during the Late Middle Ages, we come across a type of semicircular horseshoe of rectangular section, made of heavy iron plate. At least two attachment holes are arranged along the shanks ${ }^{25}$. These horseshoes often had thicker or fold-

A similar unpublished horseshoe is exhibited at the Museum of Byzant ine Civilisation of Thessaloniki. Additional, B. D. Borisov, Djadovo. Bulgarian, Dutch, Japanese Expedition, 1, Medieval Settlement and Necropolis (11th-12th Century), Tokyo 1989, 123, fig. 144. J. Čangova, Pernik, III, Sofia 1992, 185, fig. 174.1. M. Popović, The Fortress of Ras - Tvrđava Ras, Belgrade 1999, 260 fig. 223.1-2, 6-7. A. Grey, «The Metalwork», Belmont Castle. The Excavation of a Crusader Stronghold in the Kingdom of Jerusalem, eds R. P. Harper - D. Pringle (British Academy Monographs in Archaeology 10), Oxford 2000, 134, fig. 11.3.38.

${ }^{25}$ C. N. Johns, «Excavations at Pilgrims' Castle, 'Atlit, (19321933); Stables at the South-West of the Suburb», The Quarterly of the Department of Antiquities in Palestine 5 (1936), $42-43$ fig. 8, 48 fig. 15.12-13. G. Ploug - E. Oldenburg - E. Hammershaimb - R. Thomsen - F. Løkkegaard, Hama: Fouilles et Recherches 19311938, IV:3, Les petits objets médiévaux sauf les verreries et poteries (Nationalmuseets Skrifter, Større Beretninger VII), Copenhagen 1969, 58, fig. 22.2, 23.1. Nikolova, «Carevec», op.cit. (n. 18), 312 fig. 122. Popović, Ras, op.cit. (n. 24), 260 fig. 223.3-5. J. Rosen, «Crusader-period Horseshoes from Ḥorbat Bet Zeneta», 'Atiqot 39 (2000), 100 fig. 30.7-12. Grey, «The Metalwork», op.cit. (n. 24), 134, fig. 11.3.39. D. Minić - O. Vukadin, Srednjovekovni Stalać - Medieval Stalać, Belgrade 2007, 127 fig. 81.3-4. M. Brmbolić, 


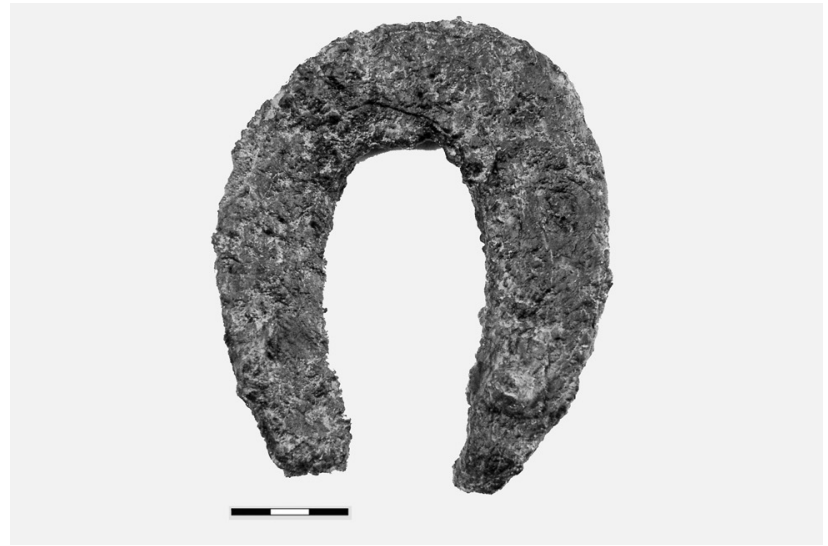

Fig. 15. Chlemoutsi. Iron horseshoe, late 13th - 14th century (Inv. Number: HM1111).

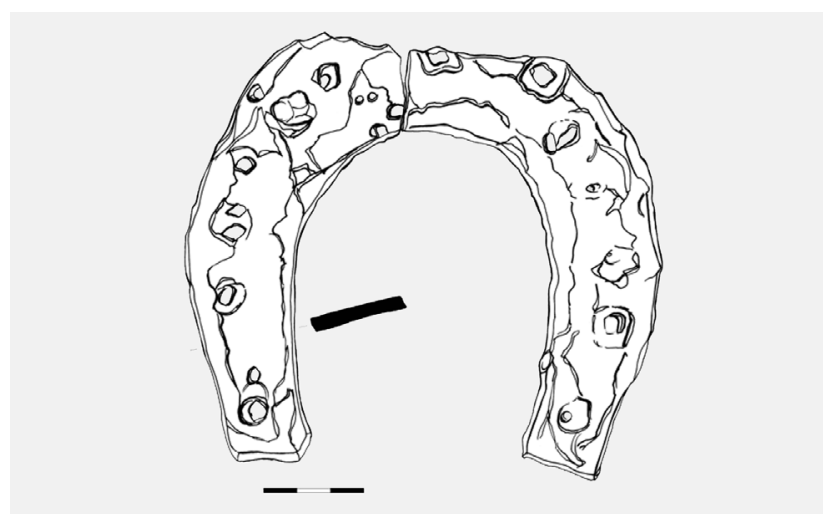

Fig. 16. Kardiakafti. Iron horseshoe, 13th-early 15th century, drawing (Inv. Number: HM978).

ed edges which formed a heel at the back of the hoof, hence facilitating the animal's gait, an element which was used progressively less after the end of the Middle Ages $^{26}$. Similar horseshoes were found at the same time

The Vršac Castle, Belgrade 2009, fig. 49.1-2. Horseshoes of similar typology with those from Elis province were found during excavation works in two boeotian sites under the administration of

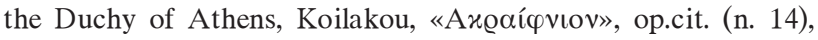
106-108, pl. 61b. S. E. J. Gerstel - M. Munn - H. E. Grossman - E. Barnes - A. H. Rohn - M. Kiel, «A Late Medieval Settlement at Panakton», Hesperia 72/2 (2003), 147-234, 165 no. 25, fig. 14.

${ }^{26}$ Rosen, «Horbat Bet Zeneta», op.cit. (n. 25), 100 fig. 30.10-11. J. Clark, The Medieval Horse and its Equipment c. 1150-1450 (Medieval Finds from Excavations in London 5), London 1995 (repr. Woodbridge 2004), 75-123, 87, 89. D. Rabovyanov, Archae-

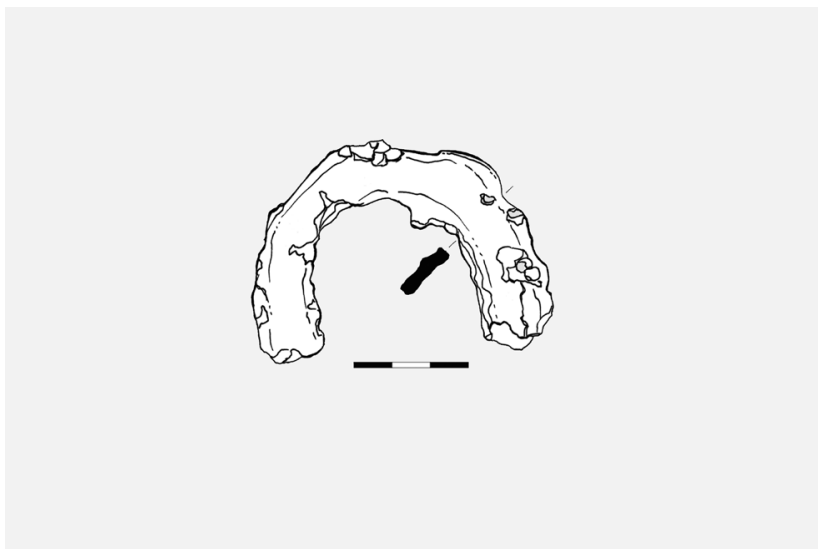

Fig. 17. Chlemoutsi. Iron horseshoe, late 13th - 14th century, drawing (Inv. Number: HM1162. $\alpha$ ).

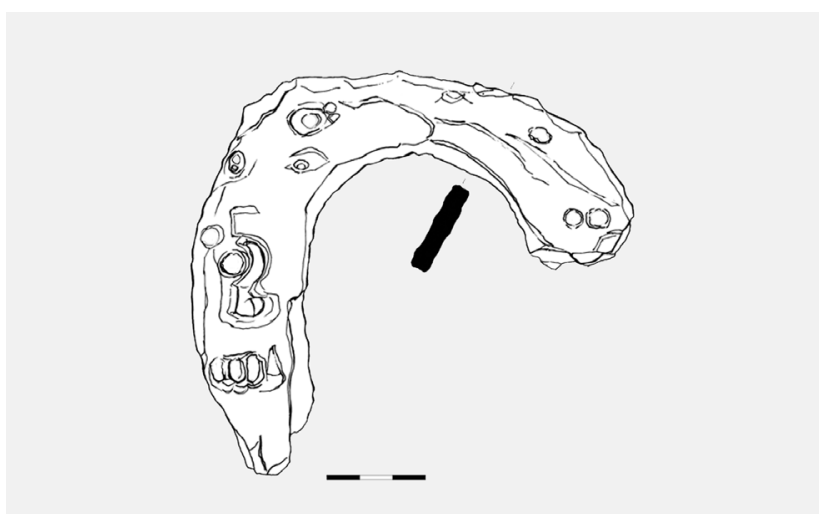

Fig. 18. Chlemoutsi. Iron horseshoe, 14th-early 15th century, drawing (Inv. Number: HM1316. $\alpha$ ).

in Western Europe, forming a group whose typology is characteristic of the Late Middle Ages ${ }^{27}$.

The horseshoes of the Frankish sites in the prefecture

ological Studies in the Southern Section of Trapezitsa, 1: The Medieval Town, Veliko Turnovo 2015, 614-616 no. 1470, 1479-1486, 1503-1508, 1524, 1534. D. Rabovyanov, Archaeological Studies in the Southern Section of Trapezitsa, 1: The Medieval Town, Veliko Turnovo 2015, 614-616 no. 1470, 1479-1486, 1503-1508, 1524, 1534. ${ }^{27}$ Clark, op.cit. (n. 26), 88-91, 96-97. The excavation finds from the crusader estates confirm the information extracted from the contemporary sources about scheduled transportation of horseshoes from Europe to the eastern Mediterranean, resulting to the predomination of a common typology, Rosen, «Horbat Bet Zeneta», op.cit. (n. 25), 204. D. Jacoby, «Aspects of Everyday Life in Frankish Acre», Crusades 4 (2005), 92 and n. 96. 
of Elis that have survived almost intact can give us some indication as regards the size of the horses that were used. However, these conclusions should be treated with caution, as studies on modern horses have proven that there is no distinct proportion between the height of the horse and the size of their hoof. Pack-horses with a bigger build usually have larger hooves than those of taller riding horses ${ }^{28}$. With these facts in mind, we observe that the maximun width of the opening in the aforementioned horseshoes ranges from 8.1 to $14 \mathrm{~cm}$, with an average of $10.87 \mathrm{~cm}$ (Figs 15-18). Measurements taken from contemporary horses, which are roughly between 1.52 and 1.68 meters tall, showed that the width of their hooves is around 12 to $14 \mathrm{~cm}$, leading to the conclusion that only larger-sized medieval horseshoes could meet the needs of a typical modern horse ${ }^{29}$. Consequently, most medieval horses must not have been taller than $1.50 \mathrm{~m}$. The measurements of horseshoes used by the Franks in the prefecture of Elis support similar experimental finds, leading to the conclusion that the medieval horse would be considered, based on current data, relatively small.

The adaptation of saddlery equipment comprises buckles and fittings usually made of iron. Two finds from the castle of Chlemoutsi were probably used to secure the leather harness that crossed the horse's belly and chest.

An iron buckle stands out because of its large dimensions and, according to the subsidiary pottery finds, dates from the late 13 th-14th century (Fig. 19). The identification of the buckle's use as a probable piece of saddlery equipment is mainly based on its dimensions but also on the material from which it is made. Since Roman period and the Late Middle Ages, works of art depicting riders illustrate how large buckles were used to fasten the saddle straps, passed across the horse's belly ${ }^{30}$. This is relevant in demonstrating the diachronic

${ }^{28}$ I. G. Sparkes, Old Horseshoes, Aylesbury 1976, 24. Clark, The Medieval Horse, op.cit. (n. 26), 29.

${ }^{29}$ Ibid., 29-32, 97-100.

${ }^{30}$ R. Cagnat - V. Chapot, Manuel d'archéologie romaine, II, Paris 1920, 293 fig. 515. For medieval examples see, The Morgan Library, MS. M638, fol. 13r (Paris, ca. 1244-1254), http://ica. themorgan.org/manuscript/page/25/158530 (accessed: 8.12.2015). J. Clark - G. Egan - N. Griffiths, «Harness fittings», The Medieval Horse and its Equipment c. 1150-1450, ed. J. Clark (Medieval Finds from Excavations in London 5), London 1995 (repr. Woodbridge 2004), fig. 46.

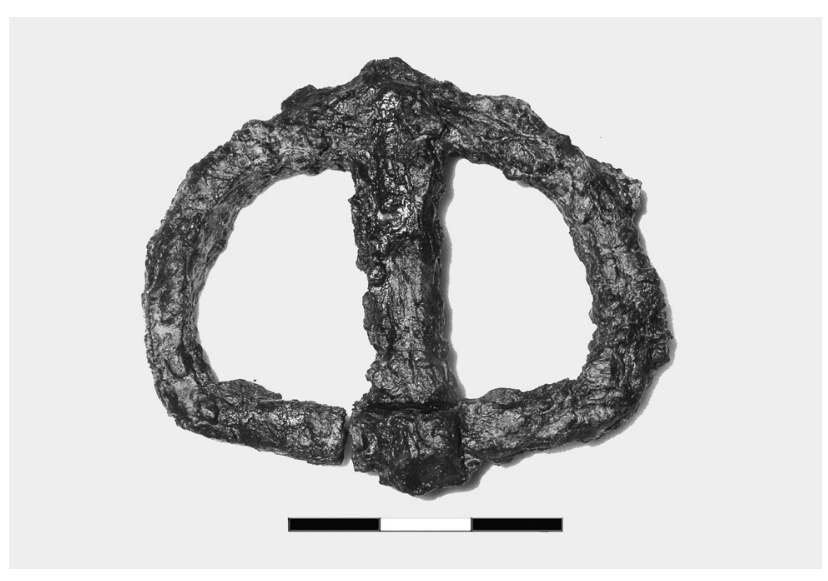

Fig. 19. Chlemoutsi. Iron buckle for the fastening of the saddle, late 13th - 14th century (Inv. Number: HM1112).

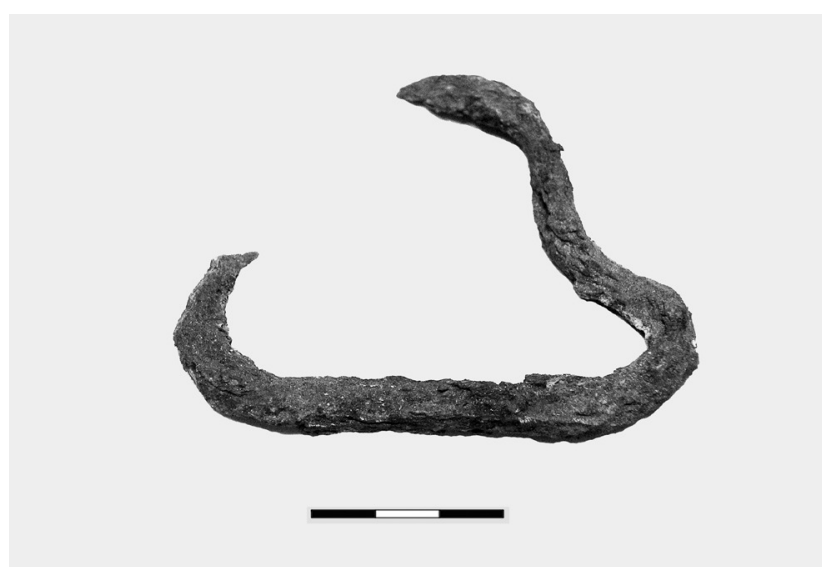

Fig. 20. Chlemoutsi. Iron fitment for bridles, 13th-early 15th century (Inv. Number: HM154).

use of riding equipment that adequately covered functional needs and become standardized.

Another hasp, made of a rectangular section iron plate, is roughly triangular in shape with bevelled corners (Fig. 20). It served as sliding clasp, ensuring flexibility in adjusting leather straps or hooks while the horse was in motion ${ }^{31}$.

Riding was, among other things, an element of social

${ }^{31}$ Clark - Egan - Griffiths, op.cit (n. 30), 61, no. 49-50, fig. 45. Similar finds: Johns, «Atlit», op.cit. (n. 25), 48, fig. 15.18. Bor isov, Djadovo, op.cit. (n. 24), 123, fig. 145. Popović, Ras, op.cit. (n. 24), 259 fig. 222.6. K. Raphael, «Crusader Arms and Armor», Knights of the Holy Land. The Crusader Kingdom of Jerusalem, ed. S. Rozenberg, Jerusalem 1999, 155 fig. 10. 
distinction and as a result the Frankish upper classes spent large amounts of money for the purchase and maintenance of horses ${ }^{32}$. Hunting activities and chivalric contests (joust and tournament) were part of the court's etiquette and complemented every major celebration $^{33}$

The war horses used by the knights of the Principality fall into two categories. Firstly, imported European horses that were tall, strong and corpulent, in comparison with eastern standards, and which were renowned for their aggression and stamina ${ }^{34}$. According to the Chronicle of Morea, during the battle of Prinitsa, in 1263, the Frank commander, Jean de Catavas, raised the spirits of his troops by claiming that their horses equalled fifteen Byzantine horses ${ }^{35}$. The element of exaggeration demonstrates the crucial role played by horses during that period in respect to the outcome of a battle.

However, the passing of time affected the Principality's lightly-armed horsemen, whose equipment and

32 J. Prawer, The World of the Crusaders, New York 1972, 89-90. The daily cost of living of a horse was particularly high and it can be compared with the daily food consumption of four manual workers, B. S. Bachrach, «Animals and Warefare in Early Medieval Europe», L'uomo di fronte al mondo animale nell'alto medioevo (Settimane di studio del Centro Italiano di Studi sull'Alto Medioevo 31), Spoleto 1985, 718-719, 750. A. Karpozilos, «Realia in Byzantine Epistolography XIII-XV c.», BZ 88 (1995), 69-70.

${ }^{33}$ Chronicle of Morea, op.cit. (n. 4), ver. 2409, ver. 3368-3369. Additionally, U. Holmes Tignor, «Life among the Europeans in Palestine and Syria in the Twelfth and Thirteenth Centuries», A History of the Crusades, gen. ed. K. M. Setton, IV, Madison 1977, 19. Jacoby, «Knightly Values», op.cit. (n. 3).

${ }^{34}$ Le voyage d'Outremer de Bertrandon de la Broquière, ed. Ch. Schefer (Recueil de voyages et de documents pour servire à l'histoire de la géographie XII), Paris 1892, 62.

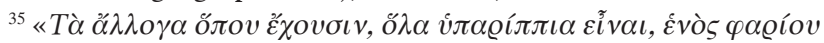

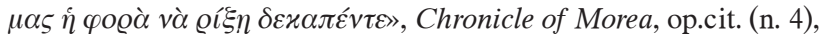
ver. $4729-4730$. organisation was, according to the limited data available, similar to the one used by the Muslim cavalry of the Middle East and the Byzantine cavalry. These corps probably used indigenous flexible, medium-sized and strong horses, which cost less to purchase and train compared to European horses ${ }^{36}$. Finally, horses of medium size as well as mules and donkeys were indispensable in all transportation activities.

Throughout the 13th century, the Principality of Achaea imported horses and horseshoes from the suzerain kingdom of Naples, as domestic breeding was not sufficient to meet supply needs. In the archives of the Anjou rulers of Naples many references are made to the transportation of war horses and pack-animals from southern Italy to Glarentza, and these increase considerably in the last decade of the 13th century ${ }^{37}$. Furthermore, Charles I of Anjou (1267-1285), following a well-established tradition in the French kingdom as well as in Sicily, created horse-breeding farms in the Principality of Achaea ${ }^{38}$. Besides, in the fertile plains of Andravida, the breeding of horses, widely known from the Byzantine period, has been a timeless occupation.

\footnotetext{
${ }^{36}$ A. Hyland, The Medieval Warhorse from Byzantium to the Cru-

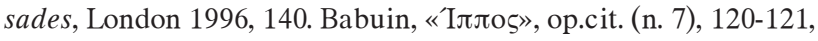
125-126.

${ }^{37}$ Actes relatifs à la Principauté de Morée 1289-1300, eds C. Perrat - J. Longnon, Paris 1967,55 no. 45-46, 64 no. 58, 77 no. 77, 90 no. 85,126 no. 132 .

38 Sampsonis, «L'administration», op.cit. (n. 1), 156-157. Ead., «La place», op.cit. (n. 1), 108.
}

\section{Provenance of figures}

Figs 1, 2: Athanasoulis, «The Triangle of Power», op.cit. (n. 2). Fig. 3: Schlumberger - Chalandon - Blanchet, Sigillographie, op.cit. (n. 6), pl. XXI.2. Figs 4a, 6, 15, 19, 20: Eleni Barmparitsa. Figs 4b, 5, 7-14, 16-18: Archaeological drawings by Aca Djordjević. 


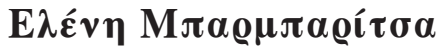

\section{ЕЕАРТНМАТА IППО $\mathrm{KEYH} \Sigma$ АПО ТО ПРІГКІПАТО ТН $\Sigma$ AХАЇА $\Sigma$ (1205-1428)}

$\mathrm{T}_{\mathrm{a}}$

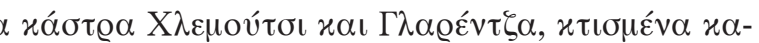

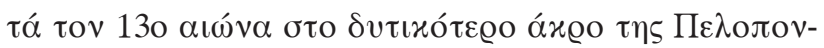

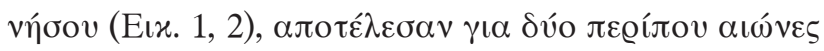

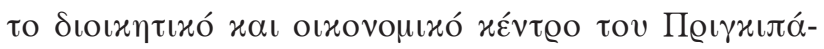

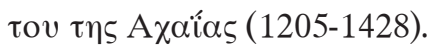

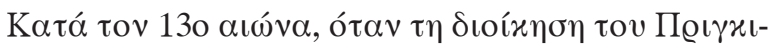

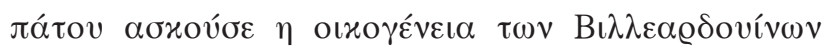

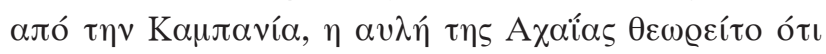

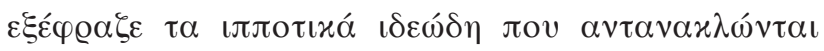

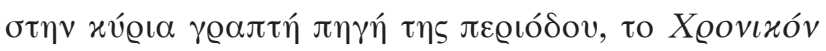

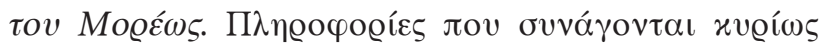

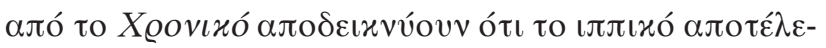

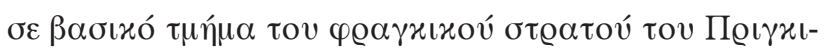

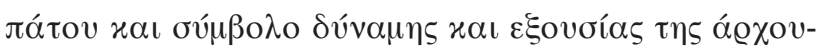

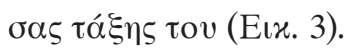

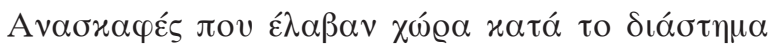

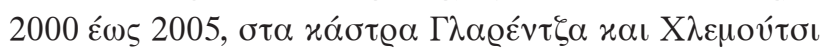

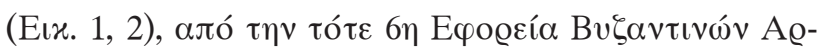

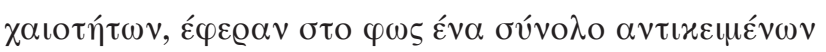

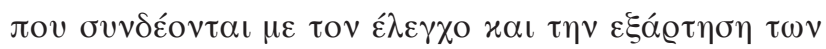

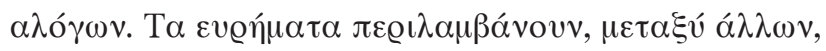

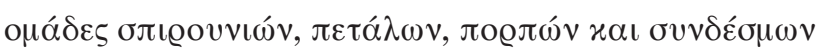

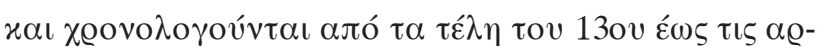

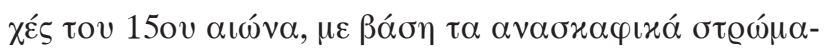

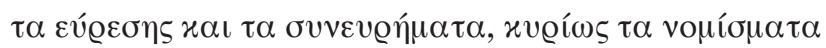

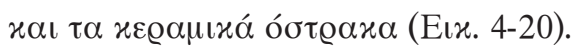

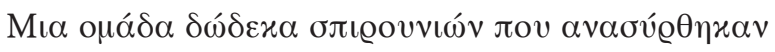

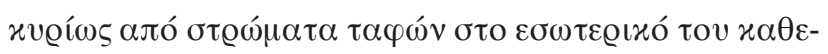

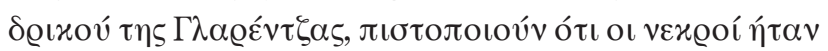

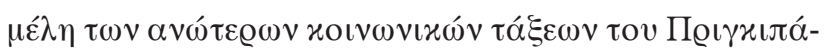

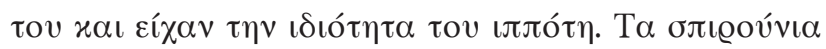

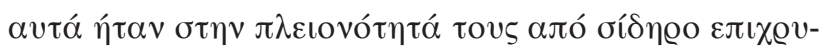

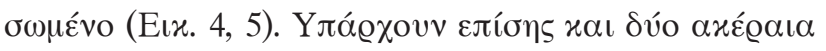

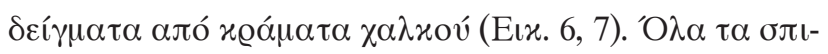

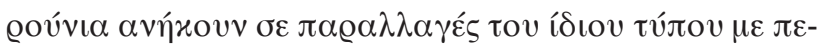

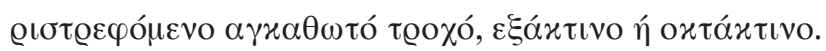

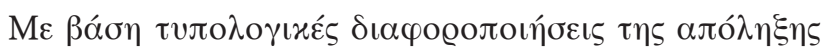

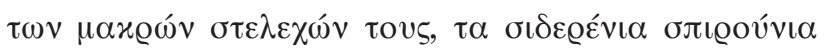

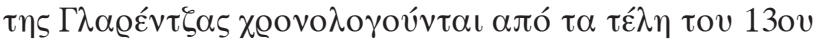

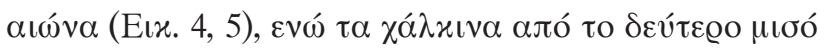

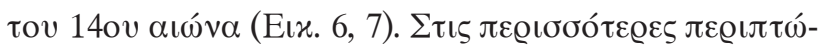

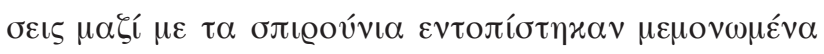

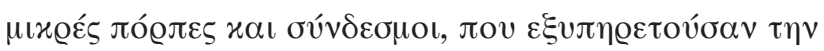

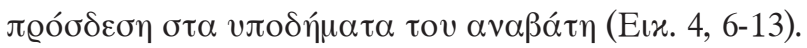

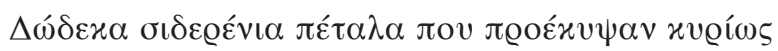

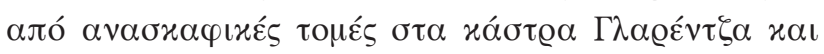

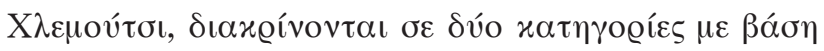

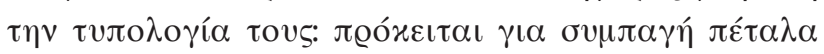

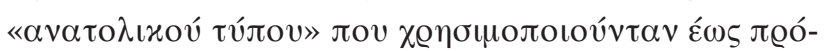

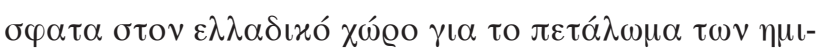

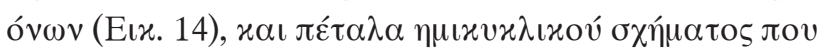

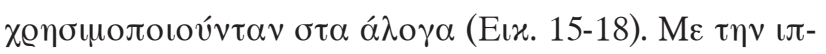

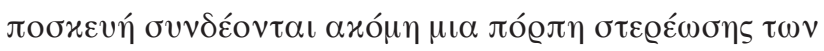

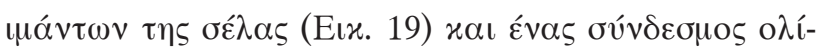
$\sigma \theta \eta \sigma \eta \varsigma \tau \omega \nu ~ \chi \alpha \lambda \iota v \omega ́ v ~(E ı x .20)$.

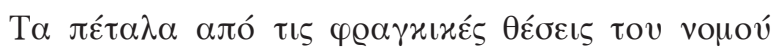

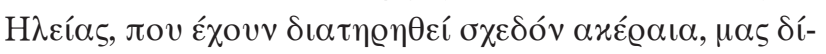

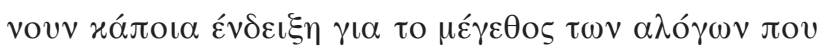

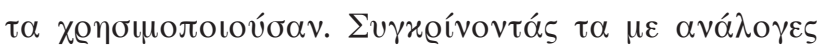

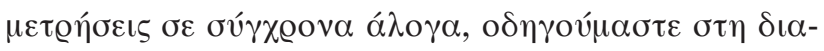

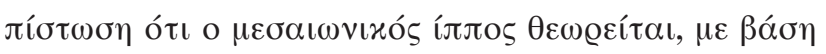

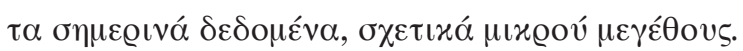

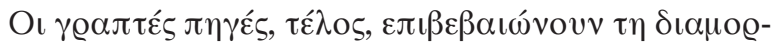

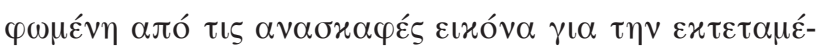

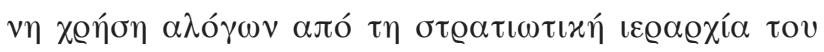

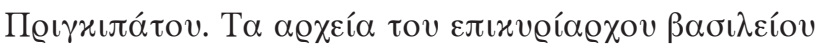

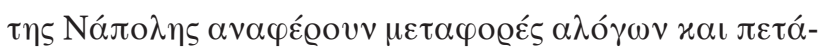

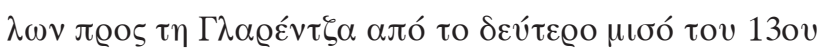

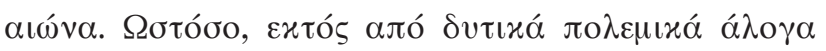

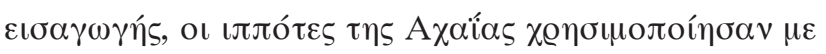

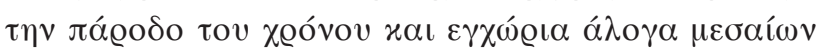

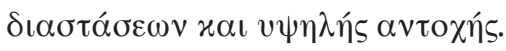

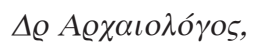
lenabarmparitsa@gmail.com 